\title{
Risk and success factors for good udder health of early lactation primiparous dairy cows
}

\author{
K. Persson Waller, ${ }^{1 *} \odot$ A A. Lundberg, ${ }^{2}$ and A.-K. Nyman ${ }^{2,3}$ (]) \\ ${ }^{1}$ Department of Animal Health and Antimicrobial Strategies, National Veterinary Institute (SVA), SE-751 89 Uppsala, Sweden \\ ${ }^{2}$ Växa Sverige, SE-104 25 Stockholm, Sweden \\ ${ }^{3}$ Department of Clinical Sciences, Swedish University of Agricultural Sciences (SLU), SE-750 07 Uppsala, Sweden
}

\begin{abstract}
We compared the management and housing of dairy heifers from calf to calving in herds that were very successful versus less successful in preventing mastitis in early lactation primiparous cows. This retrospective observational study included 170 Swedish dairy herds. Eligible herds were identified from the Swedish official milk recording scheme (SOMRS). Each herd had at least 60 cows per year, production data from 3 consecutive years, and at least 10 primiparous cows per year with their first milk recording 5 to $35 \mathrm{~d}$ after calving and their second milk recording 20 to $40 \mathrm{~d}$ after the first milk recording. In each herd, primiparous cows with a low $(\leq 75,000$ cells $/ \mathrm{mL})$ cow somatic cell count (CSCC) at both the first and second milk recording were categorized as low-low (LL); those with a high (>100,000 cells $/ \mathrm{mL}$ ) CSCC at both recordings were categorized as high-high (HH). Cows with high CSCC at the first recording and low at the second were categorized as high-low (HL). The annual proportions of LL, HL, and HH cows within each herd were calculated. Herds with an above-median proportion of LL, HL, or $\mathrm{HH}$ cows during the first year of a 3 -yr selection period, and above the third quartile proportion of LL, HL, or $\mathrm{HH}$ cows, respectively, during the second and third year were identified. These herds (LL herds, $\mathrm{n}=129$; HL herds, $\mathrm{n}=92 ; \mathrm{HH}$ herds, $\mathrm{n}=139)$ were contacted until a maximum of 60 herds per category had agreed to participate. Field technicians/veterinarians visited each herd once in the mid to late indoor season to collect data on housing and management of the heifers from birth to calving. Additional data were retrieved from the SOMRS. Associations between herd category (LL, HL, or HH) and variables collected were analyzed in 8 multivariable multinomial logistic regression submodels covering herd characteristics, milk-fed calves,
\end{abstract}

Received September 22, 2020.

Accepted November 27, 2020

*Corresponding author: karin.persson-waller@sva.se heifers in early pregnancy, heifers in late pregnancy, calving and colostrum period, miscellaneous factors, summarized heifer housing data, and general health, culling, and fertility data. A final multivariable model was built from the results of the submodels and univariable analyses. The final model showed that having a standard operating procedure for colostrum feeding was more common in LL and HL herds than in $\mathrm{HH}$ herds; the mean bulk milk SCC and overall culling rate due to udder health was higher in HH herds than in LL and HL herds; and automatic milking was less common in LL herds than in HL and HH herds. Several herd and management variables differed between herd categories in the submodels. In conclusion, we identified several success factors for herds with good udder health among early lactation primiparous cows. This knowledge can be used to improve preventive measures in dairy herds to ensure sustainable and economic milk production.

Key words: mastitis, SCC categories, housing, management

\section{INTRODUCTION}

Mastitis is a common disease in both primiparous and multiparous dairy cows. Most cases of mastitis are caused by bacterial IMI and are subclinical, and they are often identified by an increase in milk SCC. The disease is costly for the dairy industry, mainly due to reduced milk production and increased culling, and has negative effects on milk quality (Le Roux et al., 2003; Barbano et al., 2006; Nielsen et al., 2010; Hogeveen and van der Voort, 2017). The long-term consequences of mastitis on milk production and sustainability may be especially negative if primiparous cows are affected in early lactation (Hagnestam et al., 2007; De Vliegher et al., 2012). Because these cows often constitute a substantial part of the herd (e.g., around $36 \%$ of Swedish dairy cows are primiparous; Anonymous, 2020a), mastitis may have a substantial impact on herd economy.

Although the occurrence of mastitis increases with parity (e.g., Olde Riekerink et al., 2008; Persson Waller 
et al., 2009), many primiparous cows already have IMI and mastitis at calving or during the first months of lactation (e.g., Fox, 2009; Nyman et al., 2009; De Vliegher et al., 2012; Bludau et al., 2014; Lundberg et al., 2016; Persson Waller et al., 2020). We have also found that the occurrence of mastitis in early lactation primiparous cows varies markedly between Swedish herds (Lundberg et al., 2016; Persson Waller et al., 2020), indicating that herd factors are important.

The best way to reduce the incidence of mastitis is to prevent new IMI. Thus, it is important to identify risk factors for such infections and factors for successful prevention. Because many IMI are already present at calving, risk factors during heifer rearing may be particularly important. Several cow- and herd-level risk factors for IMI and mastitis in early lactation primiparous cows have been identified in studies from various countries (Fox, 2009; De Vliegher et al., 2012; SantmanBerends et al., 2012; Bludau et al., 2014, 2016), with factors being related to feeding, housing, and milking. In Sweden, only a limited number of studies have been performed. Some herd factors were identified, but they only explained a small part of the variation between herds (Svensson et al., 2006; Nyman et al., 2009). Thus, we believe that further studies to identify why some herds are more successful than others in rearing heifers with healthy udders are needed. For studies of herd-level factors, it is often necessary to include a large number of herds, which may be practically and economically challenging. One way to increase the likelihood of finding relevant results is to compare the most successful herds with those that have the most problems. Such comparisons have been used to successfully identify factors of importance for mastitis (e.g., Erskine et al., 1987; Ekman, 1998; Barkema et al., 1998; Nyman et al., 2007). However, none of those studies focused on early lactation primiparous cows.

Therefore, the aim of this project was to compare management and housing of heifers from calf to calving in herds that are very successful in preventing mastitis in early lactation primiparous cows with the same factors in herds that are less successful. Herds were selected using the proportions of primiparous cows in different cow SCC (CSCC) categories based on the first 2 milk recordings after calving (Persson Waller et al., 2020). Identifying good management and housing routines and spreading knowledge about them are both important for sustainable and economic milk production.

\section{MATERIALS AND METHODS}

This study was designed as a retrospective observational study. Each participating herd was visited once by trained personnel. For practical reasons, one half of the herds were visited during the indoor season in the beginning of 2018 and the remaining herds were visited during the corresponding period in 2019.

\section{Herd Selection}

Selection of herds was performed twice (in October/ November 2017 and 2018). In the first selection, all herds affiliated with the Swedish official milk recording scheme (SOMRS) in 2014 to $2016(\mathrm{n}=3,068,2,783$ and 2,577 herds for 2014, 2015, and 2016, respectively) were eligible for the study; in the second selection, all herds affiliated with the SOMRS in 2015 to 2017 ( $\mathrm{n}=$ $2,783,2,577$, and 2,427 herds for 2015, 2016, and 2017, respectively) were eligible. Data on herd size, lactation number, calving dates of cows, and production and SCC data from milk recordings were collected from the SOMRS. This information was used to identify herds having (1) at least 60 cows per year, (2) production data from all $3 \mathrm{yr}$, and (3) at least 10 primiparous cows per year with their first milk recording 5 to $35 \mathrm{~d}$ after calving and their second milk recording 20 to $40 \mathrm{~d}$ after the first milk recording for each of the $3 \mathrm{yr}$. Based on these criteria, a total of 1,597 herds were identified in the data from 2014 to 2016 and 1,485 herds from 2015 to 2017. As described previously (Persson Waller et al., 2020), each primiparous cow in those herds was assigned a CSCC category [low-low (LL), low-high (LH), high-high (HH), high-low (HL), or inconclusive] based on the CSCC from the 2 first milk recordings, using the following cutoffs. At each milk recording, a CSCC $\leq 75,000$ cells $/ \mathrm{mL}$ was considered low and a CSCC $>100,000$ cells $/ \mathrm{mL}$ was considered high. The CSCC cutoffs were chosen based on previous studies on CSCC after calving in noninfected and infected Swedish cows (see Persson Waller et al., 2020). The first 2 milk recordings were selected because the study focused on risk factors for IMI occurring before calving or soon after calving. After categorization of the primiparous cows, the proportions of LL, HL, and HH cows within each herd were calculated. Finally, herds having an above-median proportion of LL, HL, or HH cows during the first year of each 3-yr selection period and a proportion of LL, HL, or HH cows, respectively, above the third quartile during the second and third year were identified as herds with a stable pattern. A letter was sent via postal mail to these herds (LL herds, $\mathrm{n}=129$; HL herds, $\mathrm{n}=92$; HH herds, $\mathrm{n}=139$ ) in November with information about the project. Shortly afterward, the authors contacted the herds by telephone to ask if they wanted to participate in the study. The herds with the highest proportion of LL, HL, or HH cows were 
contacted first, and herds were contacted until a convenience sample of a maximum of 30 herds per LL, HL, and $\mathrm{HH}$ category was achieved during each selection period (i.e., a total of approximately 90 herds in 2017 and 90 herds in 2018). Then, field technicians/veterinarians $(\mathrm{n}=25)$ at a cow health and advisory service company (Växa Sverige, Stockholm) were selected and trained on study procedures. The first author (also a veterinarian) also visited some herds. Each technician/veterinarian visited 1 to 14 herds. For geographical reasons, it was not possible to limit the number of technicians. As explained below, herd visits were performed in the mid to late indoor season (mid-January to mid-April 2018 and 2019).

In the first year of the study (herd visits during 2018), herds were also asked to participate in a study involving aseptic milk sampling of all udder quarters twice per cow (colostrum and d 3-4 after calving) of at least $50 \%$ of the primiparous cows during a 12-mo period. In these cases, technicians/veterinarians made 2 additional herd visits during which they also observed the animals and took skin swab samples of the udders for bacteriological examination. The aim was to include 15 herds from each CSCC category in this study. More details on this part of the project will be presented in a separate paper.

\section{Production of Questionnaires}

Two preformed questionnaires were produced. The main questionnaire was mainly composed of yes and no questions, but it also contained multiple-choice questions and close-ended questions. Most questions had the option to give an answer other than those preprinted on the questionnaire. The aim of this questionnaire was to gather basic information about the herds as well as information on housing and management of heifer calves from birth to calving, with a special focus on the following age groups: group-housed milk-fed calves, early pregnancy (first trimester) heifers, late pregnancy (last 2 mo) heifers, and the calving and colostrum period. In addition, some general questions were asked. An overview of the questions is presented in Table 1. In the same questionnaire, forms were also available for group observations of hygiene and the presence of certain signs of disease as specified in Table 1. Before the start of the herd visits, the questionnaire was tested by the technicians/veterinarians involved in the project. The questionnaire (in Swedish) can be provided by the first author upon request. A second questionnaire aimed at gathering information about the attitudes of the animal owner or the caretaker of the dairy cows (if this was not the owner) toward the importance of different aspects of mastitis. More information about this questionnaire and the results will be presented in a separate paper.

\section{Herd Visits}

The technicians/veterinarians, who did not know the herd category of the farms, contacted the farmers and made an appointment for a herd visit taking approximately 1.5 to $2 \mathrm{~h}$. It was stressed that a person with in-depth knowledge about the management of calves and heifers at the farm should attend the meeting. At the herd visit, the technician/veterinarian asked the farmer/personnel to guide them through the facilities used for a heifer calf from birth to calving. During this process, questions from the preformed questionnaire on housing and management were asked and various conditions of the animals in certain age groups were scored and registered.

Details on scoring were provided in the questionnaire. The hygiene of each group of animals and their close environment was scored as follows: $1=$ a large proportion of the animals had areas of dried manure on several critical areas (rear, tail, udder, flank, and leg above hock/front knee) or more than a few animals had heavy contamination (coherent areas of dried manure); $2=$ more than a few animals had areas with dried manure on critical areas, more than a few animals were wet on critical areas, or the bedding was not clean and dry; or $3=$ the animals were dry and clean or had only flecks of manure on critical areas, and the bedding was dry and clean or had only a few fresh manure pads. The occurrence of hair loss without skin wounds (hair loss) and the occurrence of skin wounds with or without hair loss (skin wounds) on the outside of the hock in heifers in late pregnancy was scored as follows: $1=$ more than $25 \%$ of the animals had hair loss/skin wounds; $2=1$ to $25 \%$ of the animals had hair loss/skin wounds; or $3=$ none of the animals had hair loss/skin wounds. Evaluation of security distance in heifers in late pregnancy in a loose housing system was scored as follows after approaching the heads of the animals: $1=$ the majority of the animals avoided the test person by moving when the person approached the group; $2=$ approximately half of the animals avoided the test person; or $3=$ the majority of the animals remained standing when the test person approached the group. In the group of milk-fed calves, signs of diarrhea, coughing, or sucking were also registered (yes/no).

After finishing the main questionnaire, the technician gave the questionnaire on attitudes and a prepaid and addressed envelope to the owner/personnel and asked that a person knowledgeable about the management of the lactating cows complete the questionnaire as soon 
as possible and send it to the project leader via postal mail in the envelope provided. The farmer was promised a nonspecified gift if they sent in the questionnaire on attitudes. Otherwise, the farmer did not get any compensation for the visit but was promised first-hand information on the project results. After the herd visit, the technicians sent the questionnaire on management and housing to the project leader via postal mail.

\section{Collection of Other Data}

Data on cow breed, lactation number, and calving date and milk recording data on CSCC and milk production were collected from the SOMRS for all participating herds. Information on annual herd size, milk
SCC, and milk production, as well as production and milking systems were obtained from the same sources. Moreover, herd-level data on disease incidence rates, mortality and culling rates (both for calves and cows), and key performance indicators concerning reproduction were also collected. The data were collected for the periods April 2017 to March 2018 for herds visited during that period and for April 2018 to March 2019 for herds visited during that period.

\section{Data Handling and Editing}

The implementation of the herd visits was monitored by the first author, and reminders were sent when needed. All questionnaire data were transferred to Excel

Table 1. Contents of questionnaire (questions and observations) used at visits in dairy herds included in a study on differences in housing and management between herds with varying udder health in early lactation primiparous cows as categorized by cow SCC at the first and second milk recording after calving ${ }^{1}$

\begin{tabular}{|c|c|c|}
\hline Section & Questions & Observations \\
\hline General herd information & $\begin{array}{l}\text { Type of production, housing of lactating cows, and milking system; major } \\
\text { changes in housing and management during the last year }\end{array}$ & $\mathrm{NA}$ \\
\hline Housing of different age groups & Type of box/stall; number of animals per group; all-in/all-out; bedding & NA \\
\hline Pasture & $\begin{array}{l}\text { Age at first time on pasture; months at pasture yr } 1 \text { and } 2 \text {; stagnant water } \\
\text { on pasture; fencing of stagnant water on pasture }\end{array}$ & NA \\
\hline Milk-fed calves in group housing & $\begin{array}{l}\text { SOP for housing and movements; number of people caring for these } \\
\text { animals; SOP for feeding; feeding of whole milk; source of whole milk; } \\
\text { feeding of milk from cows with high SCC or clinical mastitis; age at } \\
\text { weaning; use of fly control; cases of diarrhea and respiratory diseases; } \\
\text { observation of sucking }\end{array}$ & $\begin{array}{l}\text { Number of animals/ } \\
\text { box; hygiene score; } \\
\text { observations of diarrhea, } \\
\text { coughing, or sucking }\end{array}$ \\
\hline Early pregnancy & $\begin{array}{l}\text { SOP for housing and movements; number of people caring for these } \\
\text { animals; SOP for feeding; feeding of corn silage or beet-pulp silage; use of } \\
\text { fly control; cases of diseases; observation of sucking }\end{array}$ & $\begin{array}{l}\text { Number of animals/box; } \\
\text { hygiene score }\end{array}$ \\
\hline Late pregnancy & $\begin{array}{l}\text { SOP for housing and movements; number of people caring for these } \\
\text { animals; SOP for feeding; feeding of corn silage or beet-pulp silage; } \\
\text { adjustment to diet of lactating cows; time with lactating cows/dry cows; } \\
\text { time in milking parlor/automatic milking unit; use of teat disinfection; } \\
\text { control of udder condition; use of fly control; cases of diseases; observation } \\
\text { of sucking, milk leakage, udder edema, udder-thigh lesions, or udder cleft } \\
\text { dermatitis }\end{array}$ & $\begin{array}{l}\text { Number of animals/ } \\
\text { box; hygiene score; hair } \\
\text { loss or skin wounds on } \\
\text { outside of hock; security } \\
\text { distance of animals }\end{array}$ \\
\hline Calving and colostrum period & $\begin{array}{l}\text { SOP for housing; number of people caring for these animals; calving site; } \\
\text { number of animals/calving site; cleaning of calving area; time of moving } \\
\text { the heifer/cow to/from calving area; time of separating calf from cow; } \\
\text { milking site during colostrum period; milking order of primiparous cows } \\
\text { relative older cows; use of teat disinfection; control of udder condition; } \\
\text { number of cows with one or more blind quarter; use of a restraining } \\
\text { method at milking; use of oxytocin at milking; use of fly control; cases of } \\
\text { diseases; observation of milk leakage, udder edema, udder-thigh lesions, } \\
\text { udder cleft dermatitis or teat papilloma }\end{array}$ & NA \\
\hline Miscellaneous factors & $\begin{array}{l}\text { Buying of cows or heifers during the last } 12 \text { mo; use of calving area for } \\
\text { sick cows; hair clipping; occurrence of teat virus infections; knowledge on } \\
\text { mastitis-causing bacteria on farm; use of milking order based on udder } \\
\text { health }\end{array}$ & NA \\
\hline
\end{tabular}

${ }^{1} \mathrm{NA}=$ not applicable; SOP $=$ standard operating procedure. 
files by a research technician at the National Veterinary Institute, and the files were double-checked against the questionnaire by the first author.

The data were then transferred to Stata (release 15.1; StataCorp LLC, College Station, TX), which was used for further data editing and analyses. A descriptive summary was done first, and when categories/ options for a question had few or no observations, one or more categories were merged when possible. For other questions, it was considered appropriate to divide the answers by forming new yes or no questions (e.g., "How is the calving area cleaned?" was changed to "Is water used for cleaning of the calving area?" and "Is all bedding removed after each calving?"). Some summary measures were also made, such as the number of changes from one housing to another from calf to calving.

\section{Statistical Analyses}

All statistical analyses were performed using Stata. Descriptive statistics were used to summarize the results from the questionnaire as well as the data from the SOMRS. Not all farmers answered all questions, nor could the technician/veterinarian observe animals in all herds because animals in a specific age group were not always present. Also, although affiliation with the SOMRS was a criterion for participating in the study, 2 of the herds left the SOMRS during the study. Hence, the number of observations in the results varies.

Associations between herd category (LL herds, HL herds, or HH herds) and the answers from the questionnaire and the data from SOMRS were investigated using univariable and multivariable multinomial logistic regression models (using the mlogit command in Stata). First, all variables were screened using univariable analysis. Next, variables with $P \leq 0.20$ and less than $5 \%$ missing data were further analyzed in 8 separate multivariable submodels for data concerning (1) herd characteristics, (2) milk-fed calves, (3) heifers in early pregnancy, (4) heifers in late pregnancy, (5) the first calving and colostrum period, (6) miscellaneous management factors, (7) summarized housing information over the whole period, and (8) general health, culling, and fertility data. A final multivariable model was also built, using the variables that were significant in each submodel, as well as those having a $P \leq 0.05$ in the univariable analyses. Collinearity was investigated for the available variables in each model using Spearman rank correlation (using the spearman command in Stata) before entering the multivariable model. If collinearity was present $(r \geq 0.70)$, only the variable with the lowest $P$-value in the univariable analysis was included in the multivariable analysis. A manual, stepwise, backward variable elimination procedure was then used for the submodels. The initial model included all available variables from the univariable analysis, and then the least significant were removed until only variables with a $P \leq 0.05$ remained. For the final multivariable model, a manual, stepwise, forward elimination procedure was applied, with variables being added to the model and kept if $P \leq 0.05$. For both the submodels and the final model, all removed variables were tested again in each model one at a time. All plausible 2-way interactions between the main effect were investigated in each submodel and the final model.

\section{RESULTS}

\section{Descriptive Statistics}

In total, 170 herds participated in the study; $63 \mathrm{LL}$ herds, $47 \mathrm{HL}$ herds, and $60 \mathrm{HH}$ herds. Two of the herds (both $\mathrm{HH}$ ) did not have information on herd size, annual milk production, bulk milk SCC (BMSCC), or proportion of primiparous cows for the year of participation, and 2 other herds had no information on annual milk production. The results from the questionnaire are presented in detail in Supplemental Tables S1 to S7 (https://doi.org/10.5281/zenodo.4471284).

As previously explained, the herds were selected based on the proportion of primiparous cows in the different SCC categories in the 3-yr period ending just over $1 \mathrm{yr}$ before the herd visits. To examine the status of the herds during the 12-mo period before the herd visit, the proportions of primiparous cows belonging to the different SCC categories were calculated for that year. The results showed that $84 \%$ of the LL herds and $78 \%$ of the $\mathrm{HH}$ herds still belonged to the top half of herds regarding the proportion of primiparous cows with $\mathrm{SCC}<75,000$ or $\mathrm{SCC}>100,000$ cells $/ \mathrm{mL}$, respectively, at the first 2 milk recordings. Among HL herds, $66 \%$ belonged to the top half of herds having primiparous cows with $\mathrm{SCC}>100,000$ cells $/ \mathrm{mL}$ at the first milk recording and $\mathrm{SCC}<75,000$ cells $/ \mathrm{mL}$ at the second milk recording.

\section{Characteristics of Study Herds}

Descriptive Summary. Descriptive data of the herd characteristics from the year they participated are presented in Table 2. Of the 170 participating herds, most $(76 \%)$ had conventional production, $89 \%$ kept the lactating cows in freestalls, and $77 \%$ housed their 
Persson Waller et al.: FACTORS FOR UDDER HEALTH IN EARLY LACTATION

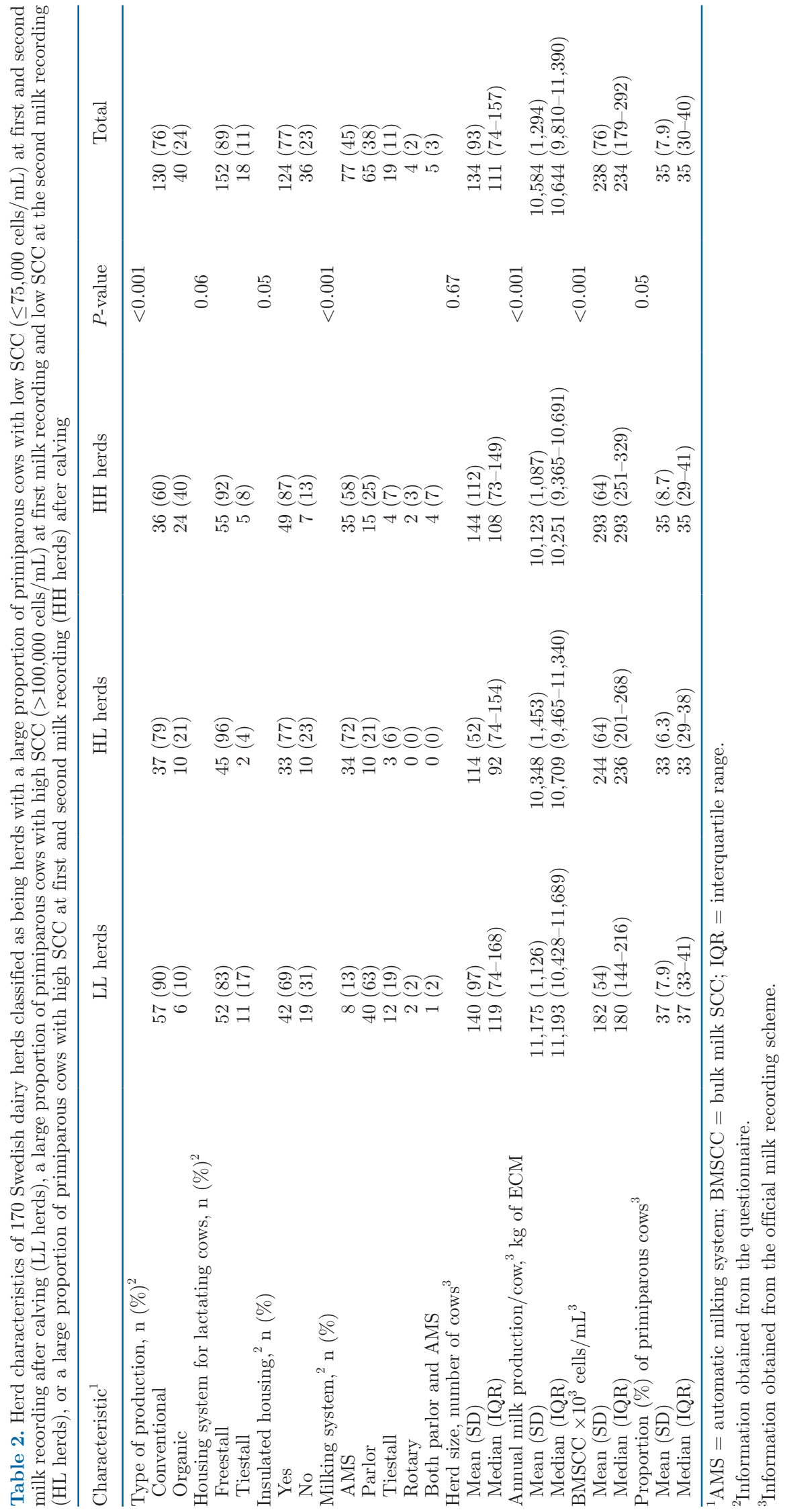


cows in an insulated building. Milking in an automatic milking system (AMS) was most common (45\%) followed by milking in a parlor $(38 \%)$. The mean herd size was 134 cows, the mean milk production was $10,584 \mathrm{~kg}$ ECM, the mean BMSCC was 238,000 cells $/ \mathrm{mL}$, and the mean proportion of primiparous cows was $35 \%$.

Multivariable Regression Analysis. Six out of 8 herd characteristics were associated with herd category at $P \leq 0.20$ in the univariable regression analysis (Table 2 ) and were included in the multivariable regression analysis. Three variables remained in the final submodel: BMSCC, milk yield, and milking system (Table $3)$. The relative risk ratio (RRR) of being an HL or HH herd, compared with an LL herd, increased with increasing BMSCC (1.02 for HL herds and 1.03 for $\mathrm{HH}$ herds for an increase of the BMSCC with 1,000 cells/ $\mathrm{mL}$ ). The RRR of being an $\mathrm{HH}$ herd, compared with an HL herd, also increased with increasing BMSCC (RRR $=1.01,95 \% \mathrm{CI}=1.00-1.02, P=0.002)$. Moreover, the RRR of being an HL herd, compared with an LL herd, decreased with increasing annual milk production (0.55 for HL herds for a 1,000-kg increase in production). Furthermore, the RRR of being an HL or HH herd, compared with an LL herd, was lower if the milking system was parlor or tie-stall milking, than if the milking system was an AMS.

\section{Management and Housing of Milk-Fed Calves}

All descriptive data and results from the univariable regression analysis are presented in Supplemental Table S1 (https://doi.org/10.5281/zenodo.4471284).

Descriptive Summary. Among the 170 farmers, $40 \%$ had written standard operating procedures (SOP) for colostrum feeding and $41 \%$ for milk feeding. The calves were fed whole milk in most herds (81\%), and among those 138 herds, 56 gave milk that was not included in the bulk tank (high SCC milk, colostrum milk, milk from cows with clinical mastitis, and so forth). Sixty-one percent of all farmers said that they fed calves with milk from high SCC cows. The time of weaning varied from 8 to $16 \mathrm{wk}$, but in most herds calves were weaned at 8 to 9 wk of age $(46 \%)$ or at 12 wk or more of age $(32 \%)$. Age at weaning was strongly associated with production system on the farm, with all organic farmers stating that the calves were weaned at an age of 12 wk or more (results not shown). A strong association also existed with milking system (results not shown), with $44 \%$ of the 77 herds with an AMS answering that they weaned the calves at 12 wk or more, compared with $27 \%$ and $11 \%$, respectively, of the farmers with parlor (65 herds) or tie-stall (19 herds) milking. Two-thirds (68\%) of the 170 farmers said that

Table 3. Multivariable multinomial logistic regression analysis of herd characteristics associated with being a herd with a large proportion of primiparous cows with low SCC at first and second milk recording after calving (LL herds), a large proportion of primiparous cows with high SCC at first milk recording and low SCC at the second milk recording (HL herds), or a large proportion of primiparous cows with high SCC at first and second milk recording (HH herds) after calving $\left(\mathrm{n}=166\right.$, pseudo $\left.\mathrm{R}^{2}=0.35\right)$

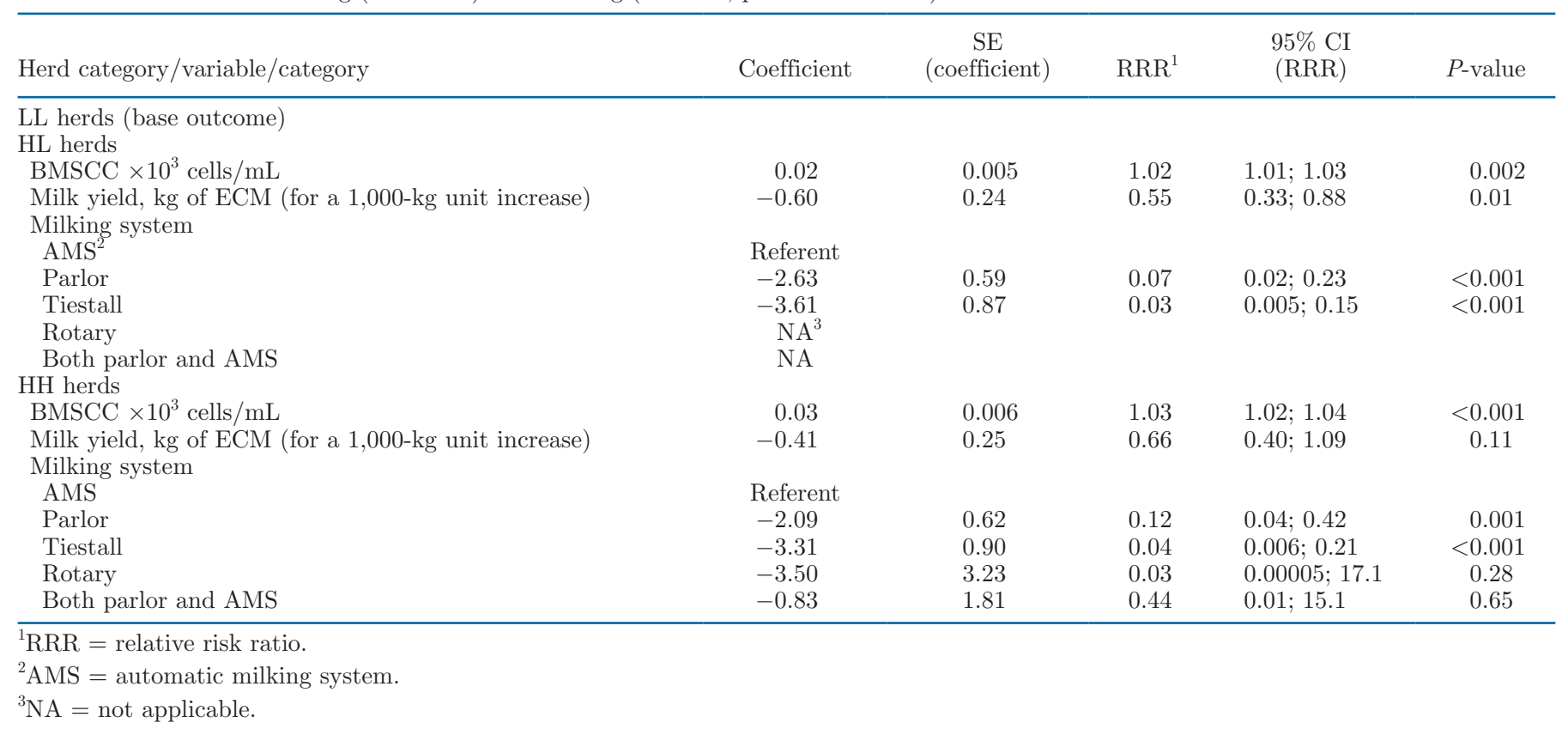


they had observed teat sucking among milk-fed calves, and the technicians/veterinarians observed teat sucking at the herd visit in $18 \%$ of the herds. Seventy-seven percent of the 170 farmers stated that they applied fly control in the area of milk-fed calves. At the herd visit, the technicians/veterinarians observed diarrhea in milk-fed calves in $24 \%$ of the 170 herds and coughing in milk-fed calves in $22 \%$. In $91 \%$ of the 170 herds, the milk-fed calves were registered as dry and clean (score $3)$.

Multivariable Regression Analysis. Of 19 questions/observations concerning milk-fed calves, 10 had an association with herd category with a $P \leq 0.20$ and were analyzed in the multivariable regression analysis. However, because 2 variables (SOP for colostrum feeding of calves and SOP for milk feeding after the colostrum period) were highly correlated $(\mathrm{r}=0.74)$, only the variable with the lowest $P$-value (SOP for colostrum feeding of calves) was used in the multivariable analysis. Two variables remained in the final model (n $=167$, pseudo $\mathrm{R}^{2}=0.09$ ): having an SOP for colostrum feeding and average age at weaning. The RRR for being an LL herd or HL herd, compared with an HH herd, was higher if the farmer had answered that they had an SOP for colostrum feeding $(4.83[95 \%$ CI $=2.04-11.4$, $P<0.001]$ for LL herds; $4.88[95 \% \mathrm{CI}=2.03-11.7, P$ $<0.001]$ for HL herds). The RRR of being an HL or HH herd, compared with an LL herd, was higher if the calves were weaned at $\geq 12$ wk of age rather than at 8 to 9 wk $(2.56[95 \% \mathrm{CI}=1.00-6.56, P=0.050]$ for $\mathrm{HL}$ herds; $5.74[95 \% \mathrm{CI}=2.23-14.76, P<0.001]$ for $\mathrm{HH}$ herds).

\section{Management and Housing of Heifers in Early Pregnancy and on Pasture}

All descriptive data and results from the univariable regression analysis are presented in Supplemental Table S2 (https://doi.org/10.5281/zenodo.4471284).

Descriptive Summary. Approximately one-third of 170 farmers had an SOP for the feeding early pregnancy. About half of the 170 farmers had observed teat sucking in these heifers during the last 12 mo. Fly control was applied in the area of these heifers in $26 \%$ of the 170 herds. Health disorders had been observed during the last $12 \mathrm{mo}$ in $21 \%$ of the 170 herds (mainly hoof and leg disorders, pneumonia, and diarrhea). Most of the 170 herds kept heifers on pasture more than 3 mo during their first year of life $(76 \%)$ and more than 4 mo during their second year of life (89\%).

Multivariable Regression Analysis. Of the 15 questions/observations concerning heifers in early pregnancy and on pasture, 6 were associated with herd category $(P \leq 0.20)$ and were included in the multivari- able regression analysis. Two variables remained in the final model $\left(n=166\right.$; pseudo $\left.R^{2}=0.05\right)$ : having an SOP for feeding and farmer observation of teat sucking during the last $12 \mathrm{mo}$. The RRR of being an LL or HL herd, compared with an $\mathrm{HH}$ herd, was higher if the farmer had answered that they had an SOP for feeding of these heifers $(2.75[95 \% \mathrm{CI}=1.18-6.39, P=0.02]$ for LL herds; $2.50[95 \% \mathrm{CI}=1.00-6.24, P=0.05]$ for HL herds). The RRR for being an HH herd, compared with an HL herd, was higher if the farmer had observed teat sucking in 1 to 3 heifers $(2.78,95 \% \mathrm{CI}=1.20-6.44$, $P=0.02)$ or in more than 3 heifers $(11.9,95 \% \mathrm{CI}$ $=1.32-107.60, P=0.03)$, compared with no observation of teat sucking. Moreover, the RRR for being an $\mathrm{HH}$ herd, compared with an LL herd, was higher if the farmer had observed teat sucking in 1 to 3 heifers (2.95, $95 \%$ CI $=1.31-6.62, P=0.009)$, than if they had no observation of teat sucking.

\section{Management and Housing of Heifers in Late Pregnancy}

All descriptive data and results from the univariable regression analysis are presented in Supplemental Table S3 (https://doi.org/10.5281/zenodo.4471284).

Descriptive Summary. Approximately one-third of the 170 farmers had an SOP for feeding of heifers in late pregnancy. In $59 \%$ of the 170 herds, heifers in late pregnancy were kept together with lactating cows. Twenty-four percent of these 100 farmers indicated that these heifers were kept in the same area as the lactating cows until 2 wk before calving, and $13 \%$ of these 100 farmers reported that the heifers were in the same area as the milking cows until calving (results not shown). Of the 170 farmers, $25 \%$ had observed teat sucking in these heifers during the last $12 \mathrm{mo}$, and $32 \%$ said that they applied fly control in the area where the heifers were kept. Almost all of the 170 farmers (91\%) stated that they did not use teat dip or teat spray on these animals. Udder edema had been observed in these heifers during the last 12 mo in $31 \%$ of the 170 herds. According to the technicians/veterinarians, these heifers were registered as dry and clean in $68 \%$ of the 170 herds.

Multivariable Regression Analysis. Of the 26 questions/observations concerning heifers in late pregnancy, 10 were associated with herd category $(P \leq$ $0.20)$ and were included in the multivariable regression analysis. Four variables remained in the final submodel: having an SOP for feeding, being in the same area as the lactating cows before calving, using fly control in housing area, and using teat-spraying or teat-dipping (Table 4). The RRR for being an LL herd or an HL herd, compared with an $\mathrm{HH}$ herd, was higher if the 
Table 4. Multivariable multinomial logistic regression analysis of factors in the period of late pregnancy of heifers associated with being a herd with a large proportion of primiparous cows with low SCC at first and second milk recording after calving (LL herds), a large proportion of primiparous cows with high SCC at first milk recording and low SCC at the second milk recording (HL herds), or a large proportion of primiparous cows with high SCC at first and second milk recording $\left(\mathrm{HH}\right.$ herds) after calving $\left(\mathrm{n}=163\right.$; pseudo $\left.\mathrm{R}^{2}=0.10\right)$

\begin{tabular}{|c|c|c|c|c|c|}
\hline Herd category, variable, category & Coefficient & $\begin{array}{c}\mathrm{SE} \\
\text { (coefficient) }\end{array}$ & $\mathrm{RRR}^{1}$ & $\begin{array}{l}95 \% \mathrm{CI} \\
(\mathrm{RRR})\end{array}$ & $P$-value \\
\hline \multicolumn{6}{|l|}{ LL herds } \\
\hline \multicolumn{6}{|c|}{ Are heifers and lactating cows in the same area before calving? } \\
\hline $\begin{array}{l}\text { Yes } \\
\text { No }\end{array}$ & $\begin{array}{l}-1.48 \\
\text { Referent }\end{array}$ & 0.42 & 0.23 & $0.10 ; 0.52$ & $<0.001$ \\
\hline \multicolumn{6}{|c|}{ Is any fly control applied in the housing area of these heifers? } \\
\hline $\begin{array}{l}\text { Yes } \\
\text { No }\end{array}$ & $\begin{array}{c}0.39 \\
\text { Referent }\end{array}$ & 0.45 & 1.48 & $0.61 ; 3.58$ & 0.38 \\
\hline \multicolumn{6}{|c|}{ Is teat dipping/spraying used before calving? } \\
\hline $\begin{array}{l}\text { Yes } \\
\text { No }\end{array}$ & $\begin{array}{c}1.60 \\
\text { Referent }\end{array}$ & 0.74 & 4.94 & $1.16 ; 21.06$ & 0.03 \\
\hline \multicolumn{6}{|l|}{ HL herds } \\
\hline \multicolumn{6}{|c|}{ Do you have an SOP for the feeding of these heifers? } \\
\hline \multicolumn{6}{|c|}{ Is any fly control applied in the housing area of these heifers? } \\
\hline $\begin{array}{l}\text { Yes } \\
\text { No }\end{array}$ & $\begin{array}{l}1.08 \\
\text { Referent }\end{array}$ & 0.45 & 2.94 & $1.22 ; 7.06$ & 0.02 \\
\hline $\begin{array}{l}\text { Is teat dip/spray used on these } \mathrm{h} \\
\text { Yes } \\
\text { No }\end{array}$ & -0.15 & 0.98 & 0.86 & $0.13 ; 5.87$ & 0.88 \\
\hline HH herds (base outcome) & - & - & - & - & - \\
\hline
\end{tabular}

${ }^{1} \mathrm{RRR}=$ relative risk ratio.

${ }^{2} \mathrm{SOP}=$ standard operating procedure.

farmer had an SOP for feeding of these heifers. The RRR for being an LL herd, compared with an HL or $\mathrm{HH}$ herd, was lower if the heifers in late pregnancy were kept together with the lactating cows before calving [0.23 compared with HH herds; $0.32(95 \%$ CI $=0.14-$ $0.74, P=0.008)$ compared with HL herds]. Moreover, the RRR of being an HL herd, compared with an $\mathrm{HH}$ herd, was higher if the farmer used fly control in the housing area of these heifers. The RRR of being an LL herd, compared with an HL or HH herd, was higher if the farmer used teat-spraying or teat-dipping of heifers in late pregnancy $(5.72[95 \% \mathrm{CI}=1.09-30.09, P=$ 0.04] in LL herds compared with HL herds).

\section{Management and Housing of Heifers and Primiparous Cows During Calving and the Colostrum Period}

All descriptive data and results from the univariable regression analysis are presented in Supplemental Table S4 (https://doi.org/10.5281/zenodo.4471284).

Descriptive Summary. In most of the 170 herds (78\%) heifers calve in individual calving pens, but it was common ( $88 \%$ of 133 herds with individual calving pens) for these pens to be used for both heifers and older cows. The time when the primiparous cow was moved from the calving area varied between herds, but $1 \mathrm{~d}$ after calving was the most common ( $43 \%$ of the 170 herds). It was most common to remove the calf from the cow within 1 to $3 \mathrm{~d}$ ( $37 \%$ of 170 herds) or as soon as possible ( $32 \%$ of 170 herds) after birth. The majority $(75 \%)$ of the 170 farmers answered that the primiparous cows were milked in the ordinary milking system during the colostrum period, and most (65\%) did not milk primiparous cows in a special order relative to older cows. Two-thirds of the 170 farmers stated that they used some restraining method on some of the primiparous cows at milking, and a similar proportion $(65 \%)$ used oxytocin injections on some of the primiparous cows to facilitate milk let-down. Moreover, fly control was used in the housing area of these animals in $45 \%$ of the 170 herds. About half $(49 \%)$ of the 170 farmers had observed udder edema and $12 \%$ had observed udder-cleft dermatitis among these animals during the last 12 mo. The majority $(79 \%)$ of the 170 farmers said that they had at least one primiparous cow 
with one or more dysfunctional udder quarters during the last 12 mo (results not shown).

Multivariable Regression Analysis. Of the 32 questions/observations concerning heifers/primiparous cows during calving and the colostrum period, 11 were associated with herd category $(P \leq 0.20)$ and were included in the multivariable regression analysis. Four variables remained in the final submodel: time for moving the animal from the calving area, milking site, milking order of primiparous cows, and use of restraining at milking (Table 5). The RRR of being an $\mathrm{HH}$ herd, compared with an LL herd, was lower if the farmer moved primiparous cows from the calving area $<3 \mathrm{~d}$ after calving compared with moving them $\geq 3 \mathrm{~d}$ after calving. Moreover, the RRR of being an HL herd, compared with an LL herd, was lower if the farmer moved primiparous cows from the calving area 2 $\mathrm{d}$ after calving compared with $\geq 3 \mathrm{~d}$ after calving. The RRR for being an HL herd, compared with an LL or $\mathrm{HH}$ herd, was higher (3.77 [95\% CI $=1.25-11.4, P=$ 0.02] compared with $\mathrm{HH}$ herds) if the farmer indicated that the primiparous cows were milked in the calving area rather than in the ordinary milking system. The RRR of being an HL or HH herd, compared with an LL herd, was lower if the farmer milked primiparous cows in a certain order relative to older cows. The RRR for being an HL or HH herd, compared with an LL herd, was lower if the farmer used restraining at milking of primiparous cows during the colostrum period.

\section{Housing and Bedding from Birth to Calving: Descriptive Summary}

All descriptive data and results from the univariable regression analysis are presented in Supplemental Table S5 (https://doi.org/10.5281/zenodo.4471284). As none of the variables were significant at $P \leq 0.20$, a multivariable analysis was not performed.

The number of changes of housing system varied, but in most of the 170 herds (75\%) the heifers moved/ changed housing system 5 to 7 times from birth to calving. Among the 170 farmers, $51 \%$ stated that they al-

Table 5. Multivariable multinomial logistic regression analysis of factors in the calving and colostrum period of primiparous heifers associated with being a herd with a large proportion of primiparous cows with low SCC at first and second milk recording after calving (LL herds), a large proportion of primiparous cows with high SCC at first milk recording and low SCC at the second milk recording (HL herds), or a large proportion of primiparous cows with high SCC at first and second milk recording (HH herds) after calving $\left(\mathrm{n}=165, \mathrm{pseudo} \mathrm{R}^{2}=0.16\right)$

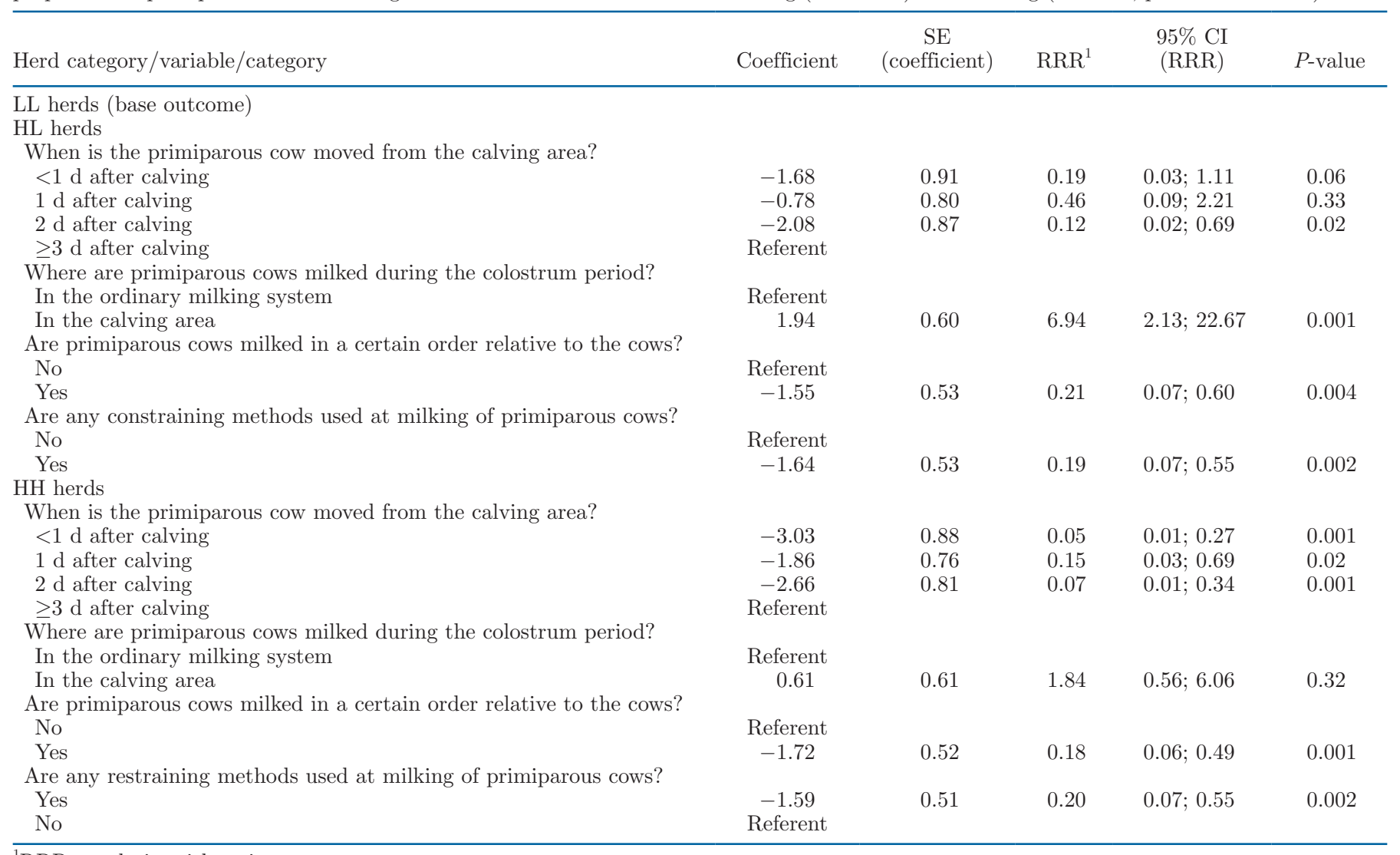

${ }^{1} \mathrm{RRR}=$ relative risk ratio. 
ways kept heifers on solid flooring (in remaining farms slatted flooring was sometimes used, mainly during early pregnancy, or no answer was given). Moreover, $66 \%$ of the 170 farmers stated that they used some type of bedding in all systems (in those farms that sometimes did not use bedding this was mainly done during early pregnancy). Recycled manure was uncommon (used in $1 \%$ of 170 herds, most farmers used chopped straw or shavings as bedding). In $15 \%$ of the 170 herds heifers were kept on deep bedding during the last 2 mo before calving.

\section{Miscellaneous Factors}

All descriptive data and results from the univariable regression analysis are presented in Supplemental Table S6 (https://doi.org/10.5281/zenodo.4471284).

Descriptive Summary. Most (78\%) of the 170 farmers trimmed the hair of their heifers, but the time point when the heifers were trimmed varied between herds. Only a few $(2 \%)$ of the 170 farmers had observed contagious teat lesions in the herd. Most (85\%) of the 170 farmers answered that they knew which udder pathogens were common in the herd. None of the HL farmers mentioned Klebsiella spp., and none of the HH farmers mentioned Trueperella pyogenes. In $32 \%$ of the 170 herds, the milking order of lactating cows was based on udder health status.

Multivariable Regression Analysis. Of the 15 questions/observations concerning miscellaneous factors, 6 were associated with herd category $(P \leq 0.20)$ and were included in the multivariable regression analysis. Only one variable remained significant in the multivariable analysis; milking order based on udder health status. The RRR of being an HL herd (RRR $=0.23,95 \% \mathrm{CI}=0.09-0.55, P=0.001)$ or an $\mathrm{HH}$ herd $(\mathrm{RRR}=0.29,95 \% \mathrm{CI}=0.14-0.64, P=0.002)$, compared with an LL herd, was lower if they used such a milking order.

\section{Health, Fertility, and Culling}

All descriptive data and results from the univariable regression analysis are presented in Supplemental Table S7 (https://doi.org/10.5281/zenodo.4471284).

Descriptive Summary. The mean mortality rate was 5.4 deaths per 100 born calves $(\mathrm{SD}=3.3)$ for calves $<24$ h old, 3.5 deaths/cullings per 100 heifer-days (SD $=4.2$ ) for heifers 1 to $59 \mathrm{~d}$ old, 1.5 deaths/cullings per 100 heifer-days $(\mathrm{SD}=2.6$ ) for heifers 60 to $179 \mathrm{~d}$ old, 1.2 deaths/cullings per 100 heifer-days $(\mathrm{SD}=2.0)$ for heifers 6 to 15 mo old, 5.2 deaths per 100 cow-days (SD $=2.9)$ for all cows, and 3.9 cullings per 100 cow-days
$(\mathrm{SD}=4.6)$ for primiparous cows in the period 1 to 90 $\mathrm{d}$ after calving. The annual mean incidence rate per 100 cow-days of veterinary-treated diseases in cows was $22.7(\mathrm{SD}=14.8)$; the rates were $10.3(\mathrm{SD}=8.5)$ for clinical mastitis, $2.7(\mathrm{SD}=3.1)$ for hoof and leg disorders, $2.9(\mathrm{SD}=2.4)$ for paresis and hypomagnesemia, and $1.1(\mathrm{SD}=1.4)$ for feeding disorders. The annual mean total culling rate per 100 cow-days of cows was $34.5(\mathrm{SD}=8.1)$; the rates were $7.6(\mathrm{SD}=4.6)$ for reproductive disorders, $8.55(\mathrm{SD}=5.2)$ for udder health disorders, and $2.7(\mathrm{SD}=2.3)$ for hoof and leg disorders. The mean proportion of heifers more than 17 mo of age that had not been bred/inseminated was $23.4 \%$ (SD $=21.5 \%$ ) , and the mean age at calving was 26.9 mo $(\mathrm{SD}=2.0 \mathrm{mo})$. The mean calving interval was 13.0 mo $(\mathrm{SD}=0.8 \mathrm{mo})$, the mean proportion of cows with more than $70 \mathrm{~d}$ from calving to first insemination was $20.0 \%(\mathrm{SD}=10.2 \%)$, and the mean proportion of cows with more than $120 \mathrm{~d}$ from calving to last insemination was $6.3(\mathrm{SD}=2.6)$. The mean proportion of difficult calvings was $1.8(\mathrm{SD}=1.7)$.

Multivariable Regression Analysis. Of the 22 variables about health, fertility, and culling, 6 were associated with herd category $(P \leq 0.20)$ and were included in the multivariable regression analysis. Two variables remained in the final submodel $(n=168$, pseudo $R^{2}=0.11$ ): culling rate due to udder health disorders and age at calving. The RRR of being an HH herd, compared with an LL herd, was higher in herds with a culling incidence rate due to udder health disorders of 5.2 to 7.8 cullings per 100 cow-days (RRR $=5.78,95 \% \mathrm{CI}=1.74-19.20, P=0.004)$ or 7.9 to 11.9 cullings per 100 cow-days $(\mathrm{RRR}=6.32,95 \% \mathrm{CI}=$ 1.94-20.5, $P=0.002$ ) compared with a culling rate of $<5.2$ cullings per 100 cow-days. Also, the RRR of being an HH herd, compared with an LL herd, was higher in herds with a culling rate of 5.2 to 7.8 cullings per 100 cow-days $(\mathrm{RRR}=3.50,95 \% \mathrm{CI}=1.16-10.6, P=0.03)$ or 7.9 to 11.9 cullings per 100 cow-days $(\mathrm{RRR}=3.83$, $95 \% \mathrm{CI}=1.30-11.3, P=0.02)$ compared with a culling incidence of $>11.9$ cullings per 100 cow-days. The RRR of being an HL herd, compared with an LL herd, was higher in herds with a culling rate of $<5.2$ cullings per 100 cow-days $(\mathrm{RRR}=3.71,95 \% \mathrm{CI}=1.11-12.3, P=$ $0.03) 5.2$ to 7.8 cullings per 100 cow-days $(\mathrm{RRR}=7.82$, $95 \% \mathrm{CI}=2.19-28.0, P=0.002)$ or 7.9 to 11.9 cullings per 100 cow-days $(\mathrm{RRR}=5.90,95 \% \mathrm{CI}=1.64-21.2$, $P=0.007)$ compared with a culling rate of $>11.9$ cullings per 100 cow-days. The RRR of being an HL herd, compared with an $\mathrm{HH}$ herd, was higher in herds with a culling rate of $<5.2$ cullings per 100 cow-days (RRR $=6.11,95 \% \mathrm{CI}=1.51-24.7, P=0.01)$ compared with a culling rate of $>11.9$ cullings per 100 cow-days. The 
RRR of being an HH herd, compared with an LL herd, was higher in herds with heifers with a higher age at first calving $(\mathrm{RRR}=4.70[95 \% \mathrm{CI}=1.41-15.7, P=$ 0.01 ] for a calving age of $25.5-26.5 \mathrm{mo}, 4.65$ [95\% CI $=$ $1.41-15.3, P=0.01]$ for a calving age of $26.6-27.9 \mathrm{mo}$, $7.98[95 \% \mathrm{CI}=2.32-27.4, P=0.001]$ for a calving age of more than $27.9 \mathrm{mo}$, compared with a calving age of $<25.5 \mathrm{mo}$ ). The RRR of being an HH herd, compared with an HL herd, was higher in herds with heifers with a higher age at first calving $(\mathrm{RRR}=4.31[95 \% \mathrm{CI}=$ $1.20-15.6, P=0.03]$ for a calving age of $26.6-27.9 \mathrm{mo}$, $5.40[95 \% \mathrm{CI}=1.53-19.0, P=0.009]$ for a calving age of $>27.9$ mo, compared with a calving age of $<25.5$ mo).

\section{Final Model of Associations Between Herd Categories and Factors from Calf to Calving}

A total of 24 variables were either significant in a submodel or had a $P \leq 0.05$ in the univariable analyses and were included in the final multivariable multinomial logistic regression analysis. Of those, 4 remained significant in the final model: BMSCC, milking system, annual culling rate due to udder health disorders, and having an SOP for colostrum feeding of calves (Table $6)$. The RRR of being an HL herd or an HH herd, compared with an LL herd, increased with increasing BMSCC; the same was also true of being an HH herd, compared with an HL herd $(\mathrm{RRR}=1.01,95 \% \mathrm{CI}=$ $1.00-1.02, P=0.001)$. Moreover, the RRR of being an HL herd or HH herd, compared with an LL herd, decreased if the milking system was a parlor or tiestall milking, rather than an AMS. Furthermore, the RRR of being an HH herd, compared with an LL herd, increased if the herd had a culling rate due to udder health disorders of 5.2 to 7.8 or 7.9 to 11.9 cullings per 100 cow-days, rather than a culling rate of $<5.2$ cullings per 100 cow-days. The RRR of being an HL herd, compared with an LL herd, increased if the herd had a culling rate due to udder health disorders of 5.2 to 7.8 cullings per 100 cow-days, rather than a culling rate of $>11.9$ cullings per 100 cow-days $(R R R=10.0$, 95\% CI $=1.89-53.1, P=0.007)$. The RRR of being an $\mathrm{HH}$ herd, compared with an HL herd, increased if the herd had a culling rate due to udder health disorders of 7.9 to 11.9 cullings per 100 cow-days (RRR = $4.05,95 \% \mathrm{CI}=1.09-15.0, P=0.04)$ or $>11.9$ cullings per 100 cow-days $(\mathrm{RRR}=6.69,95 \% \mathrm{CI}=1.39-32.2$, $P=0.02)$, rather than a culling rate of $<5.2$ cullings per 100 cow-days. Moreover, the RRR of being an $\mathrm{HH}$ herd, compared with an LL or HL herd, increased if the farmer stated that they did not have an SOP for colostrum feeding of calves $(\mathrm{RRR}=8.03,95 \% \mathrm{CI}=$ 2.66-24.2, $P<0.001$ for HH vs. HL).

\section{DISCUSSION}

According to the results of the final multivariable model, 4 variables differed significantly between herds categorized as LL, HL, or HH herds: the BMSCC, culling due to udder health, milking system, and having an SOP for colostrum feeding.

The fact that the BMSCC was lower in LL herds than in $\mathrm{HH}$ and $\mathrm{HL}$ herds is in line with previous findings that the general udder health of the herd influences that of primiparous cows (De Vliegher et al., 2004; Svensson et al., 2006; Piepers et al., 2011). However, it is also possible that high SCC in primiparous cows contributes to a high BMSCC. The udder health of the herd may also be affected by strategies for culling of cows due to udder health problems. As already mentioned, differences between herd categories were found in the present study, indicating that such culling is less common in LL herds. Moreover, results from the multivariable submodels showed that LL herds had the highest milk production, and that LL herds more often used a milking order based on udder health for all cows and, more specifically, also used a milking order for primiparous cows relative to older cows during the colostrum period, further supporting that the general udder health of the herd is important for the udder health of primiparous cows.

The milking system was another herd factor of importance. It was less likely that LL herds had AMS compared with HL and HH herds, which is in line with findings by Santman-Berends et al. (2012) studying primiparous cows until 100 DIM. Herds with AMS have also been reported to have poorer udder health, in general, than herds with conventional milking systems in other studies (Hovinen and Pyörälä, 2011; Nyman et al., 2016), most likely due to spread of IMI caused by poor teat cleaning, poor teat spraying, or poor detection of mastitis (Hovinen and Pyörälä, 2011). Milk leakage is also more common among cows in AMS herds, further increasing the risk of IMI (Persson Waller et al., 2003). The actual causes underlying the association between AMS and the herd categories are not clear. No indications have been found that the management of heifers before calving differs between herds with AMS and herds with conventional milking. Thus, the differences are more likely to be due to IMI occurring after calving. For example, primiparous cows may have difficulties adjusting to an AMS, resulting in attachment failures (Miller et al., 1995), or they may experience more stress in an AMS due to low social ranking, which may result in longer milking intervals and increased risk of milk leakage, as argued by Persson Waller et al. (2003). However, Hopster et al. (2002) did not find any differences in behavioral and physiological 
responses in primiparous cows milked in an AMS or in a conventional system. Thus, further studies are needed to clarify causes and effects.

We also found that it was more common to have an SOP for colostrum feeding of calves in LL and HL herds than in HH herds. Having such an SOP is most likely an indication of good colostrum routines, which are well known to be associated with healthy calves, and healthy calves are associated with better udder health in primiparous cows (Hultgren and Svensson, 2009). Good colostrum routines and healthy calves are also associated with better growth rates, which could result in lower age at weaning and calving, which is in line with our findings of a lower age at weaning of calves in LL herds and a lower age at calving in LL and HL herds. In support for the latter finding, having SOP for feeding was also more common in LL herds in the multivariable submodels for early and late pregnancy. Moreover, having an SOP for feeding of calves after the colostrum period was also more common in LL herds in the univariable analysis. Having an SOP for feeding is probably an indication that the overall management of the herd is good. Associations between other feeding factors, for example the amount of concentrates fed to 11- to 16-mo-old heifers (Svensson et al., 2006) and feeding sugar-beet pulp or corn silage to heifers ( $\mathrm{Ny}$ man et al., 2009), and udder health of early lactation primiparous cows have been found in previous studies.

As already mentioned, we found that age at calving differed between herd categories, with a higher age in HH herds than in LL and HL herds. This finding is in line with previous studies indicating that increased age

Table 6. Final multivariable multinomial logistic regression analysis of factors from calf to calving associated with being a herd with a large proportion of primiparous cows with low SCC at first and second milk recording after calving (LL herds), a large proportion of primiparous cows with high SCC at first milk recording and low SCC at the second milk recording (HL herds), or a large proportion of primiparous cows with high SCC at first and second milk recording (HH herds) after calving ( $\mathrm{n}=167$, pseudo $\left.\mathrm{R}^{2}=0.42\right)$

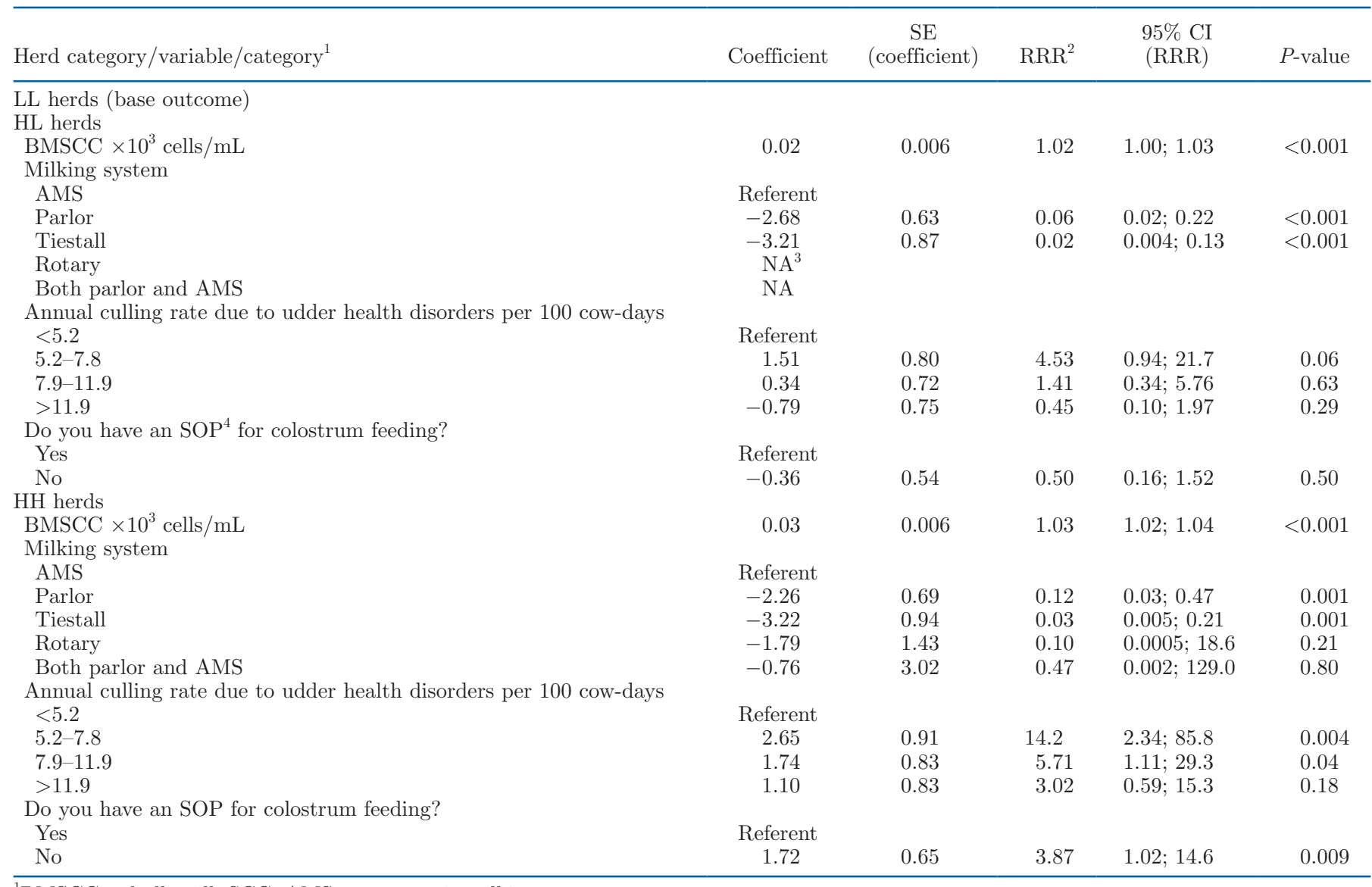

${ }^{1} \mathrm{BMSCC}=$ bulk milk SCC; AMS = automatic milking system.

${ }^{2} \mathrm{RRR}=$ relative risk ratio.

${ }^{3} \mathrm{NA}=$ not applicable.

${ }^{4} \mathrm{SOP}=$ standard operating procedure. 
at first calving is associated with poorer udder health in early lactation (Waage et al., 1998; Eastham et al., 2018; Nitz et al., 2020), although the opposite has also been found (De Vliegher et al., 2004). The reasons why age at calving is important are not clear. It may be hypothesized that differences are due to better routines and planning in LL and HL herds. However, Nitz et al. (2020) suggested that the BCS before calving, which may increase with age at calving, and a larger loss of $\mathrm{BW}$ in early lactation in primiparous cows with high BCS resulting in a more pronounced negative energy balance with negative effects on the immune response, can be of importance. This suggestion is in line with our previous finding that higher concentrations of nonesterified fatty acids before calving were associated with higher SCC in primiparous cows at first test milking (Nyman et al., 2008).

Moreover, several other factors were significant in the submodels. It was more common that the farmers had observed teat sucking among early pregnancy heifers during the previous $12 \mathrm{mo}$ in $\mathrm{HH}$ herds than in the other herds. Similar differences between herd categories were also found for farmer observation of teat sucking among milk-fed calves and heifers in late pregnancy in the univariable analyses. Teat sucking among calves and young stock, which may cause tissue damage and IMI, has also been identified as a risk factor for udder health of primiparous cows in previous studies (Schalm, 1942; Krömker et al., 2012). However, Vaughan et al. (2016) did not find any negative effects of cross sucking between dairy calves on udder health of primiparous cows. The finding that it was less common that LL herds let heifers in late pregnancy spend time with lactating cows before calving than HL and HH herds is in line with previous studies indicating that heifers should be separated from lactating cows to reduce the risk of clinical mastitis (Barkema et al., 1999). However, Santman-Berends et al. (2012) found that housing heifers together with lactating cows close to calving was protective considering subclinical mastitis. Another factor that has been identified as a risk factor for heifer mastitis is not having efficient fly control (Nickerson et al., 1995; Piepers et al., 2011) because flies may be a vector for bacteria. In our study, we found that fly control among late pregnancy heifers was more common in HL herds than in HH herds, but no other significant differences were found. However, we saw a tendency that more LL herds than HH herds used fly control among milk-fed calves and pregnant heifers. We also found that teat dipping/spraying before calving was more common in LL herds than in HL and HH herds. This finding is in line with previous studies (LopezBenavides et al., 2009; Piepers et al., 2011) that showed that teat spraying or dipping of heifers during the last weeks before calving can reduce the prevalence of certain IMI at calving. However, Edinger et al. (2000) did not see such effects. Intramammary infections before calving are most likely due to teat canals of heifers being open well ahead of calving (Krömker and Friedrich, 2009).

In addition, the time when primiparous cows were moved from the calving area, the milking site, and the use of restraining at milking during the colostrum period also differed between herd categories in the submodels. It was more common that $\mathrm{HH}$ herds let the primiparous cows stay $3 \mathrm{~d}$ or more in the calving area than a short time, which is in line with findings by Nyman et al. (2009) that the risk for high CSCC at the first test milking was higher for primiparous cows that had spent $2 \mathrm{~d}$ or more in the calving area. The increased risk for high SCC is probably due to problems keeping the calving area dry and clean, resulting in an increased risk for IMI (De Vliegher et al., 2004; Barkema et al., 1999; Piepers et al., 2011). In the study by Nyman et al. (2009), we also found that milking primiparous cows at the calving site instead of in the parlor during the colostrum period was associated with more clinical mastitis at calving and in early lactation in such cows. In the present study, however, we found that this milking practice was more common in HL herds than in $\mathrm{HH}$ and LL herds. We also found that it was more common to sometimes use restraining at milking of primiparous cows during the colostrum period in LL herds than in HL and HH herds. In contrast, Svensson et al. (2006) found that use of restraining was associated with an increased risk for elevated SCC. The divergent findings are difficult to interpret. Use of restraining may be due to individual cow behavior, but in some herds it may be used as a standard management routine when starting to milk a primiparous cow. In Sweden, the most common restraining method is a steel anti-kicking-bow attached to one side of the cows with one end at the groin and one end over the back. The role of restraining in udder health may warrant more studies.

Mastitis control programs, such as the 5-point or 10-point plans, have been around for several decades, but those programs did not address mastitis in heifers and primiparous cows. In 2014, however, the National Mastitis Council published a 10-point plan on prevention and control of heifer mastitis (NMC, 2014) mainly based on the review by De Vliegher et al. (2012). Several of the points in that plan were also identified as success and risk factors in the present study, further supporting their importance. A factor included in the plan that was also included as a variable in the present study, but was not identified as a risk factor, was the 
presence of udder edema. This disease has, however, mainly been associated with clinical mastitis (Waage et al., 2001).

In this study we used a new approach to categorize udder health in early lactation primiparous cows; the reasons behind this approach were given in our previous publication (Persson Waller et al., 2020). In short, we based our CSCC cutoffs on previous studies of CSCC of infected and noninfected Swedish primiparous cows. As the distribution of mastitis-causing pathogens and the breeding material differ between countries, and given that no consensus exists on optimal CSCC cutoffs, we believe our approach was most appropriate for the purpose of the study. Moreover, we used the term early lactation based on the International Dairy Federation definition (IDF, 2011) that early lactation equals the first $100 \mathrm{~d}$ of lactation. Although we did not follow the cows for a full $100 \mathrm{~d}$, we believe that this expression was the most representative for the period studied.

The herds included in the study were selected based on their data over a 36-mo period to find herds with a stable herd pattern. For practical purposes, the selection period ended just over 1 yr before the actual herd visits, meaning that the categorization of the herds as LL herds, HL herds, and HH herds could have possibly changed. However, the examination of the herd status for the 12-mo period before the herd visits combined with results on BMSCC for the 3 groups of herds indicate that the categorization was correct in most of the herds. The selection of herds was performed using the highest quartile or $50 \%$ of the eligible herds. It may be argued that selection of herds based on exact cutoffs rather than relative cutoffs would have been better, but because the suitable levels of such cutoffs are not known, we believe that our approach was the best given the information available.

The results found in the present study may not be applicable to all herds in Sweden because the participating herds were larger than the average herd in the SOMRS (the average herd size was 92 cows/herd in 2018-2019), had slightly lower BMSCC than in the SOMRS (a calculated average of 249,000 cells $/ \mathrm{mL}$ ), but had similar milk production $(10,417 \mathrm{~kg}$ of ECM on average for all herds in SOMRS) (Anonymous, 2020a,b). Moreover, in this study a smaller proportion of herds with conventional production were included ( $83 \%$ of herds are conventional in SOMRS), and a larger proportion of herds with AMS (33\% AMS in SOMRS) and herds with free-stalls (54\% free-stalls in SOMRS) compared with all herds in the SOMRS. However, the results found may still be useful for other herds than those included in the study.

We also think that the results should be interpreted with caution because the risk for type I errors (i.e., finding significant results despite no true associations existing) increases when many risk factors are tested. However, as many of the associations have been found in previous studies and are biologically plausible, the results in general are considered valid.

\section{CONCLUSIONS}

Using a new approach, comparing success and problem herds selected based on SCC categories, several herd-level success factors of importance for being a herd with good udder health among early lactation primiparous cows were identified, such as having an SOP for colostrum feeding, low BMSCC, and low culling rate due to udder health problems and not having AMS. In addition, other factors identified as important differences between herd categories were herd milk yield, age at weaning, having an SOP for feeding of heifers in early and late pregnancy, farmer observation of teat sucking among heifers in early pregnancy, heifers in late pregnancy spending time with lactating cows before calving, fly control among heifers in late pregnancy, using teat disinfection before calving, time when the cow is moved from the calving area, milking site during the colostrum period, milking order of primiparous versus multiparous cows during the colostrum period, restraining at milking during the colostrum period, and having a milking order based on udder health and age at first calving. This knowledge can be used to improve preventive measures in dairy herds, ensuring sustainable and economic milk production.

\section{ACKNOWLEDGMENTS}

Financial support from the Swedish Farmers' Foundation for Agricultural Research is gratefully acknowledged as is the contribution of the farmers, animal technicians, and veterinarians at Växa Sverige (Stockholm, Sweden) and the laboratory technicians at SVA (Uppsala, Sweden). The authors have no conflicts of interest.

\section{REFERENCES}

Anonymous. 2020a. Husdjursstatistik 2020 [Cattle statistics 2020]. Pages 1-39. Växa Sverige, Uppsala, Sweden.

Anonymous. 2020b. Redogörelse för husdjursorganisationernas djurhälsovård 2018/2019 [Account of animal health care by animal health organisations 2018/2019]. Pages 1-52. Växa Sverige, Uppsala, Sweden.

Barbano, D. M., Y. Ma, and M. V. Santos. 2006. Influence of raw milk quality on fluid milk shelf life. J. Dairy Sci. 89(Suppl. 1):E15-E19. https://doi.org/10.3168/jds.S0022-0302(06)72360-8.

Barkema, H. W., Y. H. Schukken, T. J. G. M. Lam, M. L. Beiboer, G. Benedictus, and A. Brand. 1998. Management practices associated with low, medium, and high somatic cell counts in bulk milk. 
J. Dairy Sci. 81:1917-1927. https://doi.org/10.3168/jds.S0022 -0302(98)75764-9.

Barkema, H. W., Y. H. Schukken, T. J. G. M. Lam, M. L. Beiboer, G. Benedictus, and A. Brand. 1999. Management practices associated with the incidence rate of clinical mastitis. J. Dairy Sci. 82:16431654. https://doi.org/10.3168/jds.S0022-0302(99)75393-2.

Bludau, M. J., A. Maeschli, F. Leiber, P. Klocke, J. A. Berezowski, M. Bodmer, and B. Vidondo. 2016. The influence of the rearing period on intramammary infections in Swiss dairy heifers: A cross-sectional study. Prev. Vet. Med. 129:23-34. https://doi.org/ 10.1016/j.prevetmed.2016.04.013.

Bludau, M. J., A. Maeschli, F. Leiber, A. Steiner, and P. Klocke. 2014. Mastitis in dairy heifers: Prevalence and risk factors. Vet. J. 202:566-572. https://doi.org/10.1016/j.tvjl.2014.09.021.

De Vliegher, S., L. K. Fox, S. Piepers, S. McDougall, and H. W. Barkema. 2012. Invited review: Mastitis in dairy heifers: Nature of the disease, potential impact, prevention, and control. J. Dairy Sci. 95:1025-1040. https://doi.org/10.3168/jds.2010-4074.

De Vliegher, S., H. Laevens, H. W. Barkema, I. R. Dohoo, H. Stryhn, G. Opsomer, and A. de Kruif. 2004. Management practices and heifer characteristics associated with early lactation somatic cell count of Belgian dairy heifers. J. Dairy Sci. 87:937-947. https:// doi.org/10.3168/jds.S0022-0302(04)73238-5.

Eastham, N. T., A. Coates, P. Cripps, H. Richardson, R. Smith, and G. Oikonomou. 2018. Associations between age at first calving and subsequent lactation performance in UK Holstein and HolsteinFriesian dairy cows. PLoS One 13:e0197764. https://doi.org/10 .1371/journal.pone.0197764.

Edinger, D., B.-A. Tenhagen, P. Kalbe, G. Klünder, B. Baumgärtner, and W. Heuwiser. 2000. Effect of teat dipping with a germicide barrier teat dip in late gestation on intramammary infection and clinical mastitis during the first 5 days post-partum in primiparous cows. J. Vet. Med. A 47:463-468. https://doi.org/10.1046/j.1439 $-0442.2000 .00305 . \mathrm{x}$

Ekman, T. 1998. A study of dairy herds with constantly low or constantly high bulk milk somatic cell count-with special emphasis on management. PhD Thesis. Swedish University of Agricultural Sciences, Uppsala, Sweden.

Erskine, R. J., R. J. Eberhart, L. J. Hutchinson, and R. W. Scholz. 1987. Herd management and prevalence of mastitis in dairy herds with high and low somatic cell counts. J. Am. Vet. Med. Assoc. 190:1411-1416.

Fox, L. K. 2009. Prevalence, incidence and risk factors of heifer mastitis. Vet. Microbiol. 134:82-88. https://doi.org/10.1016/j.vetmic 2008.09.005

Hagnestam, C., U. Emanuelson, and B. Berglund. 2007. Yield losses associated with clinical mastitis occurring in different weeks of lactation. J. Dairy Sci. 90:2260-2270. https://doi.org/10.3168/jds .2006-583.

Hogeveen, H., and M. van der Voort. 2017. Assessing the economic impact of an endemic disease: The case of mastitis. Rev. Sci. Tech. 36:217-226. https://doi.org/10.20506/rst.36.1.2623.

Hopster, H., R. M. Bruckmaier, J. T. N. Van der Werf, S. M. Korte, J. Macuhova, G. Korte-Bouws, and C. G. van Reenen. 2002. Stress responses during milking; Comparing conventional and automatic milking in primiparous dairy cows. J. Dairy Sci. 85:3206-3216. https://doi.org/10.3168/jds.S0022-0302(02)74409-3.

Hovinen, M., and S. Pyörälä. 2011. Invited review: Udder health of dairy cows in automatic milking. J. Dairy Sci. 94:547-562. https:/ /doi.org/10.3168/jds.2010-3556.

Hultgren, J., and C. Svensson. 2009. Lifetime risk and cost of clinical mastitis in dairy cows in relation to heifer rearing conditions in southwest Sweden. J. Dairy Sci. 92:3274-3280. https://doi.org/10 $.3168 /$ jds.2008-1678.

IDF. 2011. Suggested interpretation of mastitis terminology. Bulletin of the IDF: 448/2011. International Dairy Federation, Brussels, Belgium.

Krömker, V., and J. Friedrich. 2009. Teat canal closure in non-lactating heifers and its association with udder health in the consecutive lactation. Vet. Microbiol. 134:100-105. https://doi.org/10.1016/j .vetmic.2008.09.002.
Krömker, V., F. Pfannenschmidt, K. Helmke, R. Andersson, and N. T. Grabowski. 2012. Risk factors for intramammary infections and subclinical mastitis in post-partum dairy heifers. J. Dairy Res. 79:304-309. https://doi.org/10.1017/S0022029912000222.

Le Roux, Y., F. Laurent, and F. Moussaoui. 2003. Polymorphonuclear proteolytic activity and milk composition change. Vet. Res. 34:629-645. https://doi.org/10.1051/vetres:2003021.

Lopez-Benavides, M. G., J. H. Williamson, S. J. Lacy-Hulbert, and R. T. Cursons. 2009. Heifer teats sprayed in the dry period with an iodine teat sanitizer have reduced Streptococcus uberis teat-end contamination and less Streptococcus uberis intra-mammary infections at calving. Vet. Microbiol. 134:186-191. https://doi.org/10 .1016/j.vetmic.2008.09.027.

Lundberg, Å., A.-K. Nyman, A. Aspán, S. Börjesson, H. Ericsson Unnerstad, and K. Persson Waller. 2016. Udder infections with Staphylococcus aureus, Streptococcus dysgalactiae, and Streptococcus uberis at calving in dairy herds with suboptimal udder health. J. Dairy Sci. 99:2102-2117. https://doi.org/10.3168/jds.2015-9487.

Miller, R. H., L. A. Fulton, B. Erez, W. F. Williams, and R. E. Pearson. 1995. Variation in distances among teats of Holstein cows: Implications for automated milking. J. Dairy Sci. 78:1456-1462. https://doi.org/10.3168/jds.S0022-0302(95)76767-4.

Nickerson, S. C., W. E. Owens, and R. L. Boddie. 1995. Mastitis in dairy heifers: Initial studies on prevalence and control. J. Dairy Sci. 78:1607-1618. https://doi.org/10.3168/jds.S0022-0302(95)76785 -6 .

Nielsen, C., S. Østergaard, U. Emanuelson, H. Andersson, B. Berglund, and E. Strandberg. 2010. Economic consequences of mastitis and withdrawal of milk with high somatic cell count in Swedish dairy herds. Animal 4:1758-1770. https://doi.org/10.1017/ S1751731110000704.

Nitz, J., V. Krömker, D. Klocke, N. Wente, Y. Zhang, and M. Tho Seeth. 2020. Intramammary infections in heifers-Time of onset and associated risk factors. Animals (Basel) 10:1053. https://doi .org/10.3390/ani10061053.

NMC. 2014. Heifer mastitis prevention and control plan. The National Mastitis Council, New Prague, MN. https://www.nmconline.org/ wp-content/uploads/2018/04/NMC-Factsheet-Heifer-Mastitis-and -Control.pdf

Nyman, A. K., U. Emanuelson, K. Holtenius, K. L. Ingvartsen, T. Larsen, and K. Persson Waller. 2008. Metabolites and immune variables associated with somatic cell counts of primiparous dairy cows. J. Dairy Sci. 91:2996-3009. https://doi.org/10.3168/jds.2007 -0969 .

Nyman, A., Y. Persson, and M. Mörk. 2016. Celltal i svenska mjölkbesättningar och hos svenska kor. [Somatic cell counts in Swedish dairy herds and in Swedish cows]. Svensk Vet. 68:17-23.

Nyman, A.-K., T. Ekman, U. Emanuelson, A. H. Gustafsson, K. Holtenius, K. Persson Waller, and C. Hallén Sandgren. 2007. Risk factors associated with the incidence of veterinary-treated clinical mastitis in Swedish dairy herds with a high milk yield and a low prevalence of subclinical mastitis. Prev. Vet. Med. 78:142-160. https://doi.org/10.1016/j.prevetmed.2006.10.002.

Nyman, A.-K., U. Emanuelson, A. H. Gustafsson, and K. Persson Waller. 2009. Management practices associated with udder health of first-parity dairy cows in early lactation. Prev. Vet. Med. 88:138-149. https://doi.org/10.1016/j.prevetmed.2008.08.005.

Olde Riekerink, R. G. M., H. W. Barkema, D. F. Kelton, and D. T. Scholl. 2008. Incidence rate of clinical mastitis on Canadian dairy farms. J. Dairy Sci. 91:1366-1377. https://doi.org/10.3168/ jds.2007-0757.

Persson Waller, K., B. Bengtsson, A. Lindberg, A. Nyman, and H. Ericsson Unnerstad. 2009. Incidence of mastitis and bacterial findings at clinical mastitis in Swedish primiparous cows-Influence of breed and stage of lactation. Vet. Microbiol. 134:89-94. https:// doi.org/10.1016/j.vetmic.2008.09.004.

Persson Waller, K., Å. Lundberg, and A.-K. Nyman. 2020. Udder health of early lactation primiparous dairy cows based on somatic cell count categories. J. Dairy Sci. 103:9430-9445. https://doi.org/ $10.3168 /$ jds.2020-18346. 
Persson Waller, K., T. Westermark, T. Ekman, and K. SvennerstenSjaunja. 2003. Milk leakage-An increased risk in automatic milking systems. J. Dairy Sci. 86:3488-3497. https://doi.org/10.3168/ jds.S0022-0302(03)73953-8.

Piepers, S., K. Peeters, G. Opsomer, H. W. Barkema, K. Frankena, and S. De Vliegher. 2011. Pathogen group specific risk factors at herd, heifer and quarter levels for intramammary infections in early lactating dairy heifers. Prev. Vet. Med. 99:91-101. https:// doi.org/10.1016/j.prevetmed.2011.02.010.

Santman-Berends, I. M. G. A., R. G. M. Olde Riekerink, O. C. Sampimon, G. van Schaik, and T. J. G. M. Lam. 2012. Incidence of subclinical mastitis in Dutch dairy heifers in the first 100 days in lactation and associated risk factors. J. Dairy Sci. 95:2476-2484. https://doi.org/10.3168/jds.2011-4766.

Schalm, O. 1942. Streptococcus agalactiae in the udder of heifers at parturition traced to sucking among calves. Cornell Vet. 32:39-60.

Svensson, C., A.-K. Nyman, K. Persson Waller, and U. Emanuelson. 2006. Effects of housing, management, and health of dairy heifers on first-lactation udder health in southwest Sweden. J. Dairy Sci. 89:1990-1999. https://doi.org/10.3168/jds.S0022-0302(06)72266 -4 .
Vaughan, A., G. G. Miguel-Pacheco, A. M. de Pasillé, and J. Rushen. 2016. Reciprocated cross sucking between dairy calves after weaning off milk does not appear to negatively affect udder health or production. J. Dairy Sci. 99:5596-5603. https://doi.org/10.3168/ jds.2015-9504.

Waage, S., S. A. Ødegaard, A. Lund, S. Brattgjerd, and T. Røthe. 2001. Case-control study of risk factors for clinical mastitis in dairy heifers. J. Dairy Sci. 84:392-399. https://doi.org/10.3168/ jds.S0022-0302(01)74489-X.

Waage, S., S. Sviland, and S. A. Ødegaard. 1998. Identification of risk factors for clinical mastitis in dairy heifers. J. Dairy Sci. 81:12751284. https://doi.org/10.3168/jds.S0022-0302(98)75689-9.

\section{ORCIDS}

K. Persson Waller ๑ https://orcid.org/0000-0002-8481-4313

A.-K. Nyman @ https://orcid.org/0000-0002-6643-0404 